\title{
Growth of black spruce seedlings planted in burned, logged, and undisturbed boreal mixedwood stands of southeastern Manitoba
}

\author{
by G.G. Wang ${ }^{1,2}$ and J. Su ${ }^{1}$
}

Growth of black spruce seedling planted in burned, harvested, and undisturbed boreal mixedwood stands was studied in southeastern Manitoba. Although seedlings on each site were subjected to similar light competition (measured by $\%$ of full sunlight received at the middle crown of each crop seedling in 1998), mean annual growth of height, root collar diameter and aboveground biomass was different among the three sites, with burned > logged > undisturbed. During each of last seven years (1992 to 1998 except 1997), the burned site had greater annual height growth than the logged and undisturbed sites. Similarly, the logged site had greater height growth than the undisturbed site except 1997 and 1998. Relative competition intensity (calculated based on annual height growth from 1992 to 1998) fluctuated between 0.70 to 0.76 on the undisturbed site, increased from 0.48 to 0.73 on the logged site, and increased from 0.23 to 0.74 on the burned site. Relative competition intensity remained similar in the most recent three years (1996-1998) despite larger differences found in earlier years (1992-1995) between sites. A significant relationship was found between the relative competition intensity and $\%$ full sunlight on each site. Results from this case study suggested that, by affecting the development of competing vegetation, the type/intensity of past disturbances created different competition dynamics for black spruce seedlings planted on the burned, logged and undisturbed sites.

Keywords: interspecific competition, vegetation management, competition dynamics, plantation

La croissance de semis d'épinette noire plantés dans des peuplements mélangés boréaux brûlés, récoltés et non perturbés, a été étudiée dans le sud-est du Manitoba. Même si les semis de chaque site ont été soumis à une compétition semblable pour la lumière (mesurée en \% de l'ensoleillement total reçu sur le milieu de la cime de chaque semis d'arbre à être récolté en 1998), la croissance annuelle moyenne de la hauteur, du diamètre au collet et de la biomasse au-dessus du sol était différente sur les trois sites, soit brûlés > récoltés > non perturbés. Au cours de chacune des sept dernières années (de 1992 à 1998, à l'exception de 1997) le site brûlé montrait une croissance annuelle en hauteur plus importante que les sites récoltés et non perturbés. De même le site récolté démontrait une croissance en hauteur plus importante que le site non perturbés sauf en 1997 et en 1998. L'intensité relative de la compétition (calculée selon la croissance annuelle en hauteur de 1992 à 1998) a varié entre 0,70 et 0,76 sur le site non perturbé, a augmenté de 0,48 à 0,73 sur le site récolté, et a augmenté de 0,23 à 0,74 sur le site brûlé. L'intensité relative de la compétition est demeurée semblable au cours des dernières années (1996-1998) malgré les plus grandes différences retrouvées au cours des années antérieures (1992-1995) entre les sites. Une relation significative a été trouvée entre l'intensité relative de la compétition et le \% d'ensoleillement total sur chacun des sites. Les résultats de cette étude de cas laissent entendre que, en affectant le développement de la végétation compétitrice, le type/intensité des perturbations passées a engendré des dynamiques de compétition différentes pour les semis d'épinette noire plantés sur des sites brûlés, récoltés et non perturbés.

Mots-clés: compétition interspécifique, contrôle de la végétation, dynamiques de la compétition, plantation

\section{Introduction}

Black spruce (Picea mariana (Mill.) BSP) and white spruce (Picea glauca (Moench) Voss) are major species for establishing conifer plantations on boreal mixedwood sites across Canada. However, planted spruce seedlings are often subjected to severe competitions from neighbouring vegetation (e.g., DeLong 1991, Lieffers et al. 1993, MacIsaac and Navratil 1996). As a result, light, nutrient, water and space available to spruce seedlings are greatly reduced by competing vegetation (e.g., Jobidon 1994, Malik and Timmer 1998), especially by those woody plants that overtop crop seedlings (e.g., Wagner and Radosevich 1991, Wang et al. 2000). Managing competing vegetation thus becomes critical to the establishment of spruce plantations (e.g., Walstad and Kuch 1987, Campbell 1990, Wagner 1994).

Previous studies on the growth of planted conifer seedlings under vegetation competition were almost exclusively concerned

\footnotetext{
${ }^{1}$ Department of Biology and Centre for Forest Interdisciplinary Research, The University of Winnipeg, Winnipeg, Manitoba R3B 2E9.

${ }^{2}$ Corresponding author. Email: wang @ uwinnipeg.ca
}

with plantations established after timber harvesting (e.g., DeLong 1991, Wagner and Radosevich 1991, Comeau et al. 1993, Jobidon 1994, Puettmann and Reich 1995, Wang et al. 2000). Although most spruce plantations on mixedwood sites have been established after timber harvesting, spruce plantations have also been established after fire disturbances in southeastern Manitoba. Our field observations suggested that there was a great difference in the composition of competing vegetation between the two types of plantations. After fire, aspen (Populus tremuloides Michx.) and other hardwood species often establish themselves quickly through vegetative regeneration and become dominant for 50 and more years (Bergeron and Dubuc 1989). Before self-thinning of hardwood species, development of understory species is generally poor (De Grandpre et al. 1993). As a result, spruce seedlings planted after fire disturbance are mainly competing with hardwood tree species, predominantly aspen. Timber harvesting, however, results in rapid increases in shrub species abundance mainly due to the expanding of existing species (De Grandpre and Bergeron 1997, Kneeshaw et al. 1999). This is especially the case in southeastern Manitoba where softwood- 
selective logging has been practised on mixedwood stands due to lack of utilization of aspen. Residual aspen trees on selectively logged sites prohibit vigorous production and growth of aspen suckers while conifer removal greatly increases understory light intensity and thus encourages a rapid growth of understory species. Consequently, planted spruce seedlings face competing vegetation mainly consisting of shrub species such as beaked hazel (Corylus cornuta Marsh.) and/or mountain maple (Acer spicatum Lam.). Clearly, the difference in the composition of competing vegetation and, perhaps more importantly, the post-disturbance growth dynamics of different competing species need to be considered in developing vegetation management strategies.

The objective of this retrospective case study was to compare growth of planted black spruce seedlings currently growing under the same stressed light condition among burned, logged, and undisturbed sites. To quantify growth reduction due to competition, black spruce seedlings growing in a competition-free environment were also included in the study.

\section{Materials and Methods \\ Study site}

The study was conducted in southeastern Manitoba (approximately $\left.50^{\circ} 47^{\prime} \mathrm{N}, 95^{\circ} 45^{\prime} \mathrm{E}\right)$. Three young black spruce plantations were selected according to the following criteria: (1) site originally supported aspen mixedwood stands, (2) site had a flat topography and fine textured soils with few $(<5 \%)$ coarse fragment, (3) planted seedlings were currently under similar levels of light competition, and (4) competition-free seedlings could be found adjacent to each site. Plantation 1 (the burned site) was burned in September 1983 by intensive crown fire and planted with paperpot 408 stock in May 1984. Seedlings currently grew under a closed canopy dominated by trembling aspen (about $9.5 \mathrm{~m}$ tall) with some overtopping shrubs such as wild rose (Rosa acicularis Lindl.; about $1.1 \mathrm{~m}$ ), beaked hazel (about $1.6 \mathrm{~m}$ ) and choke cherry (Prunus virginiana L.; about $2.4 \mathrm{~m}$ tall). Plantation 2 (the logged site) was harvested in winter 1987 and planted with small container stock in June 1988. The site was clear cut using conventional cut and skid (Chainsaw and skidder), with tree length-topped and limbed in the bush. Seedlings currently grew under a closed canopy dominated by the mixture of beaked hazel (about $1.5 \mathrm{~m}$ ), mountain maple (about $2.7 \mathrm{~m}$ ), and aspen (about $4.8 \mathrm{~m}$ ). Plantation 3 (the undisturbed site) was planted with paperpot 408 stock in May 1985 under a sparse canopy of trembling aspen and dense beaked hazel (currently about $2.5 \mathrm{~m}$ ). For all three plantations, a mechanical trenching treatment was applied before planting and no tending treatment was applied since planting. Using the field procedure of Wang et al. (1994), all three sites were classified into the same relative soil moisture regime of 5 or subhygric and similar soil nutrient regime of medium to rich.

\section{Seedling selection and measurement}

On each site, a homogeneous area of about $500 \mathrm{~m}^{2}$ was selected and all seedlings (58, 78 and 58 seedlings from the burned, logged, and undisturbed sites, respectively) within the area were selected in 1998. Immediately adjacent to the burned site, 10 seedlings were randomly selected from a small area of about $200 \mathrm{~m}^{2}$, where overtopping vegetation was absent due to extreme mechanical disturbance at the time of planting. These seedlings served as a reference in calculating relative competition intensity for the burned site. Part of the plantation on the logged site was treated with herbicide in fall 1991 and maintained a competition-free environment (i.e., lack of overtopping vegetation) since then. Twenty seedlings were randomly selected from the herbicide-applied area and served as a reference to calculate relative competition intensity for both the logged and the undisturbed sites. The logged and the undisturbed sites are located $200 \mathrm{~m}$ apart on either side of a logging road. All selected seedlings were numbered and tagged for the convenience of subsequent measurements.

For each seedling, photosynthetically active radiation (PAR) was measured in July using an 80-cm AccuPAR Ceptometer (Decagon Device Inc. 1996) under clear sky conditions. Each PAR measurement was derived from the average of two readings taken at right angles; two measurements (one in the morning between 10:00 and 12:00 a.m. and another in the afternoon between 14:00 and 16:00 p.m.) were taken at the middle crown of each seedling (Wang et al. 2000). Self-shading was avoided by carefully bending the seedling away from the Ceptometer. Open-sky PAR $\left(\mathrm{PAR}_{0}\right)$ was recorded at oneminute intervals using a LI-190SA quantum sensor connected to LI 1000 datalogger (Li-Cor Inc. 1988). The percentage of full sunlight at the middle (PFL) were calculated as:

$$
\text { [1] } \mathrm{PFL}=\mathrm{PAR} / \mathrm{PAR}_{0} \times 100
$$

The PFL used as the measure of light environment of each seedling were the means of the morning and afternoon measurements. Using the seedling as the plot centre, a 1-m radius circular plot was set up around each seedling. On each plot, percent shrub cover above the middle crown of the seedling was estimated, and root collar diameter of each tree regenerated after the disturbance was measured.

In September, height (HT), annual height growth from 1998 (HG98) to the earliest year accurately identifiable by counting growth whorls was measured to the nearest $\mathrm{cm}$ using a ruler. Root collar diameter $\left(\mathrm{D}_{0}\right)$ of each seedling was measured to the nearest $0.1 \mathrm{~mm}$ using a digital calliper. Regression equations were also developed to estimate root collar diameter $\left(\mathrm{D}_{0}, \mathrm{~mm}\right)$ from height (HT, cm):

[2] The burned site: $\mathrm{D}_{0}=0.166 \mathrm{HT}^{0.921}$

$$
\mathrm{R}^{2}=0.921 \quad \mathrm{rMSE}=0.21 \mathrm{~mm}
$$

[3] The undisturbed site: $\mathrm{D}_{0}=0.059 \mathrm{HT}^{1.152} \quad \mathrm{R}^{2}=0.892 \quad \mathrm{rMSE}=0.16 \mathrm{~mm}$

where $\mathrm{R}^{2}$ and rMSE are corrected coefficient of determination and root mean square error resulted from nonlinear regression analysis (Wilkinson 1990). On each plantation, twenty black spruce seedlings, selected to cover the range of size variation, were harvested for measuring aboveground biomass. Each harvested seedling was cut at the root collar, brought back to the laboratory, and oven-dried at $70^{\circ} \mathrm{C}$ to a constant mass. Regression equations were developed to estimate aboveground biomass $(A B, g)$ from root collar diameter $\left(\mathrm{D}_{0}, \mathrm{~mm}\right)$ and height $(\mathrm{HT}, \mathrm{cm})$ :

[4] The burned site:

$\mathrm{AB}=0.341\left(\mathrm{D}_{0}^{2 * \mathrm{HT}}\right)^{0.617} \quad \mathrm{R}^{2}=0.957 \quad \mathrm{rMSE}=0.22 \mathrm{~g}$ 
Table 1. A brief summary of growth and light environment of black spruce seedlings planted on burned, logged, and undisturbed sites. Values shown are means, with ranges in parenthesis. $H T=$ height, $D_{0}=$ root collar diameter, $A B=$ aboveground biomass, $P F L=$ percent full sunlight measured at the middle crown of each seedling, $\mathrm{SC}=$ percent shrub cover above the middle crown of each seedling, and $\mathrm{BA}=\mathrm{basal}$ area calculated from root collar diameter of trees regenerated after disturbance. Note that mature aspen canopy was present in the undisturbed site

\begin{tabular}{|c|c|c|c|}
\hline $\begin{array}{l}\text { Disturbance } \\
\text { Plantation age (year) }\end{array}$ & $\begin{array}{c}\text { Burned } \\
15\end{array}$ & $\begin{array}{c}\text { Logged } \\
11\end{array}$ & $\begin{array}{c}\text { Undisturbed } \\
14 \\
\end{array}$ \\
\hline \multicolumn{4}{|l|}{ Seedling Growth: } \\
\hline $\mathrm{HT}(\mathrm{cm})$ & $183(60-366)$ & $101(35-295)$ & $81(29-186)$ \\
\hline $\mathrm{D}_{0}(\mathrm{~mm})$ & $20.1(8.6-46.0)$ & $13.4(2.5-35.5)$ & $9.4(3.1-21.7)$ \\
\hline $\mathrm{AB}(\mathrm{g})$ & $384.9(60.7-1431.6)$ & $170.0(2.7-1215.6)$ & $61.4(3.6-307.1)$ \\
\hline \multicolumn{4}{|c|}{ Competition environment: } \\
\hline PFL (\%) & $8.5(2.7-29.1)$ & $9.6(2.5-28.7)$ & $9.9(2.9-29.7)$ \\
\hline $\mathrm{SC}(\%)$ & $14(0-55)$ & $45(15-80)$ & $65(40-80)$ \\
\hline $\mathrm{BA}\left(\mathrm{m}^{2} / \mathrm{ha}\right)$ & $21.7(1.5-78.7)$ & $10.5(0-48.5)$ & N/A \\
\hline
\end{tabular}

[5] The logged site:

$\mathrm{AB}=0.021\left(\mathrm{D}_{0}^{2 * \mathrm{HT}}\right)^{0.855} \quad \mathrm{R}^{2}=0.967 \quad \mathrm{rMSE}=0.21 \mathrm{~g}$

[6] The undisturbed site:

$\mathrm{AB}=0.268 \mathrm{D}_{0}^{2.289} \quad \mathrm{R}^{2}=0.981 \quad \mathrm{rMSE}=0.10 \mathrm{~g}$

where $\mathrm{R}^{2}$ and $\mathrm{rMSE}$ are defined as above. A brief summary of black spruce seedling growth and competition environment is given in Table 1.

\section{Data analysis}

For the burned and the undisturbed sites, height at the $11^{\text {th }}$ year since planting was calculated from height in 1998 and height growth measurements, and root collar diameter at the $11^{\text {th }}$ year since planting was estimated from height (Equations [2] and [3]). Basal area was calculated for each seedling based on measured or estimated root collar diameter. Aboveground biomass was estimated based on height and/or root collar diameter (Equations [4-6]). Mean annual growth since planting as well as mean annual growth for the first 11 years since planting were calculated for height, root collar diameter, basal area, and aboveground biomass and compared among the burned, logged and undisturbed sites.

For each year from 1992 to 1998, relative competition intensity (RCI) of each seedling was calculated based on annual height growth (HG) on the burned, logged and undisturbed sites. The calculation was not possible for all three sites prior to 1992 due to lack of competition-free seedlings. The calculation method was proposed by Wilson and Keddy (1986) and modified by Markham and Chanway (1996):

[7] $\mathrm{RCI}=\left(\mathrm{HG}_{\mathrm{OPEN}}-\mathrm{HG}_{\mathrm{X}}\right) / \mathrm{HG}_{\mathrm{Y}}$

where $\mathrm{HG}_{\mathrm{OPEN}}$ is the mean height growth of reference seedlings; $\mathrm{HG}_{\mathrm{X}}$ is height growth of seedling $\mathrm{x}$ under competition; $\mathrm{HGy}$ is $\mathrm{HG}_{\mathrm{OPEN}}$ or $\mathrm{HG}_{\mathrm{X}}$, whichever is larger. RCI ranges from 1 to -1. Positive values indicate the presence of competition with surrounding vegetation, negative values indicate facilitation by the surrounding vegetation, and zero indicates that the surrounding vegetation has no effect (Markham and Chanway 1996, Davis et al. 1998).

Graphical comparisons were used to examine the change of height growth and RCI between 1992 and 1998 and the difference in height growth and RCI between the burned, logged and undisturbed sites. Simple correlation analysis was used to examine the relationship between RCI and light on each site.

\section{Results}

The mean annual growth of height, root collar diameter, basal area, and aboveground biomass during the first 11 years (the minimum plantation age) or over the entire period since planting were different among the three sites, with the burned $>$ logged $>$ undisturbed sites (Table 2).

Annual height growth was greater on the burned site than on the other two sites each year from 1992 to 1998, except for1997 (Fig. 1). Similarly, annual height growth was greater on the logged site than on the undisturbed site each year from 1992 to 1996 . No differences were observed between the logged and the undisturbed site in 1997 and 1998 (Fig. 1).

On the burned site, $R C I$ increased from 1992 to 1997 but remained at the similar level between 1997 to 1998 (Fig. 2). On the logged site, $R C I$ displayed a slightly increasing trend overall since 1992, with little change in the last two years (1997 and 1998). On the undisturbed site, however, $R C I$ remained relatively stable from 1992 to 1998 , fluctuating between 0.70 and 0.76. Large differences in RCI were found among the three sites in 1992, 1993 and 1994, with the undisturbed > logged > burned sites. The undisturbed site had a higher RCI than the logged and burned sites in 1995. There were little differences in RCI among the three sites in the last three years (1996, 1997 and 1998).

Significant relationships were found between RCI and \% full sunlight measured in 1998 on the burned $(\mathrm{r}=-0.590)$, logged $(\mathrm{r}=-0.686)$, and undisturbed $(\mathrm{r}=-0.582)$ sites.

\section{Discussion}

Despite growing under a currently similar light condition, growth of planted black spruce seedlings differed significantly among the three sites, which differed initially in disturbance type/intensity and subsequently in composition of competing vegetation. Black spruce seedlings grew fastest under the aspen canopy on the burned site, slowest under dense tall shrubs (mainly beaked hazel) on the undisturbed site, and intermediate under a mixture of the shrubs (mainly beaked hazel and mountain maple) and aspen on the logged site. Given similar soil moisture and nutrient conditions, seedling growth differences are likely attributed to difference in competition.

If light had remained at the level measured in 1998 over the entire period since planting, and thus comparable among the three plantations (Table 1), the observed differences in growth could have been attributed to the species-specific competition for underground resources (DeLong 1991, Burton 1993). However, comparisons on RCI revealed no significant differences 
Table 2. Mean annual growth (with standard deviation in parentheses) of black spruce seedlings on the burned, logged and undisturbed sites

\begin{tabular}{lccc}
\hline $\begin{array}{l}\text { Disturbance } \\
\text { \# of seedlings }\end{array}$ & $\begin{array}{c}\text { Burned } \\
(\mathrm{n}=58)\end{array}$ & $\begin{array}{c}\text { Logged } \\
(\mathrm{n}=78)\end{array}$ & $\begin{array}{c}\text { Undisturbed } \\
(\mathrm{n}=58)\end{array}$ \\
\hline $\begin{array}{l}\text { Mean growth during first 11 years after planting: } \\
\text { Height (cm/year) }\end{array}$ & $11.2(0.63)$ & $8.2(0.31)$ & $4.5(0.33)$ \\
Root collar diameter (mm/year) & $1.3(0.07)$ & $1.04(0.05)$ & $0.49(0.04)$ \\
Basal area (cm/year) (cm/year) & $15.88(1.57)$ & $12.32(1.23)$ & $2.44(0.29)$ \\
Aboveground biomass (g) & $7.54(0.95)$ & $1.46(0.20)$ \\
Mean growth since planting & $17.51(1.65)$ & & $5.4(0.33)$ \\
Height (cm/year) & & $9.0(0.47)$ & $0.63(0.04)$ \\
Root collar diameter (mm/year) & $12.0(0.69)$ & $1.19(0.08)$ & $5.59(0.87)$ \\
Basal area (cm²/year) & $1.26(0.07)$ & $16.52(2.71)$ & $4.02(0.74)$ \\
Aboveground biomass (g/year) & $23.54(2.36)$ & $13.32(2.89)$ & \\
\hline
\end{tabular}

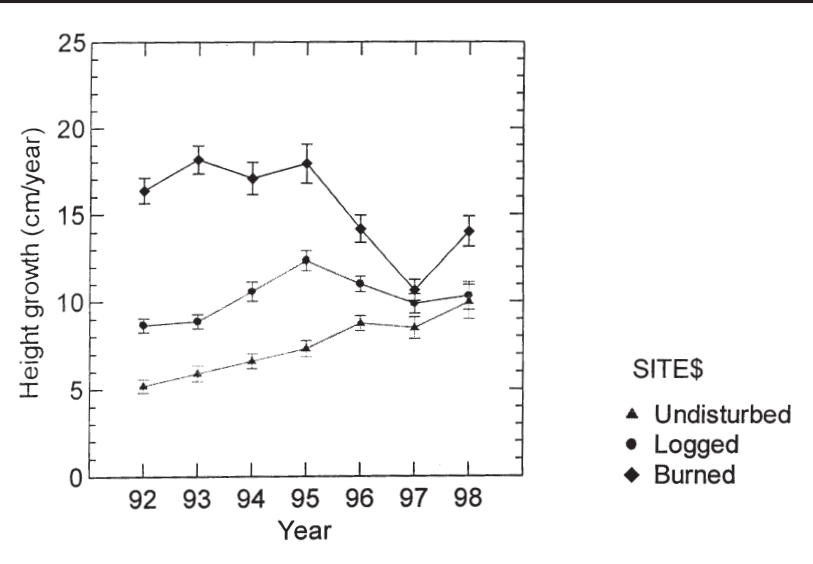

Fig. 1. Comparisons of annual height growth of planted black spruce seedlings among the three sites. Error bars shown are standard errors.

among the three sites from 1996 to 1998 despite differences in earlier years (Fig. 2), which suggested that similar competition intensities resulted from similar degrees of canopy shading regardless of canopy types. This result, together with the significant relationship found between RCI and light, suggested that competition intensity could be assessed by the $\%$ full sunlight received by each seedling without considering species composition of competing vegetation. It appeared that competition for light was a useful surrogate measure of the overall effect of resource competition on the growth of black spruce seedlings planted on these studied sites. Previous studies have reported that light is the factor most limiting the vigour and growth of crop seedlings, with soil moisture and nutrients limiting growth only when light is in adequate supply (e.g., Reed et al. 1983, Brand 1986).

Because the interspecific competition between black spruce and other woody plants likely changes over time due to vegetation growth (Burton 1993), the observed differences in the growth of black spruce seedlings among the three sites may have resulted from different competition dynamics since planting. Although currently under the same level of light stress, seedlings of different plantations may have experienced different competition environments during the past. The instantaneous assessment of competition in 1998 (measured by \% full sunlight) in our study did not reflect competition condition beyond the immediate past, and each plantation displayed different com-

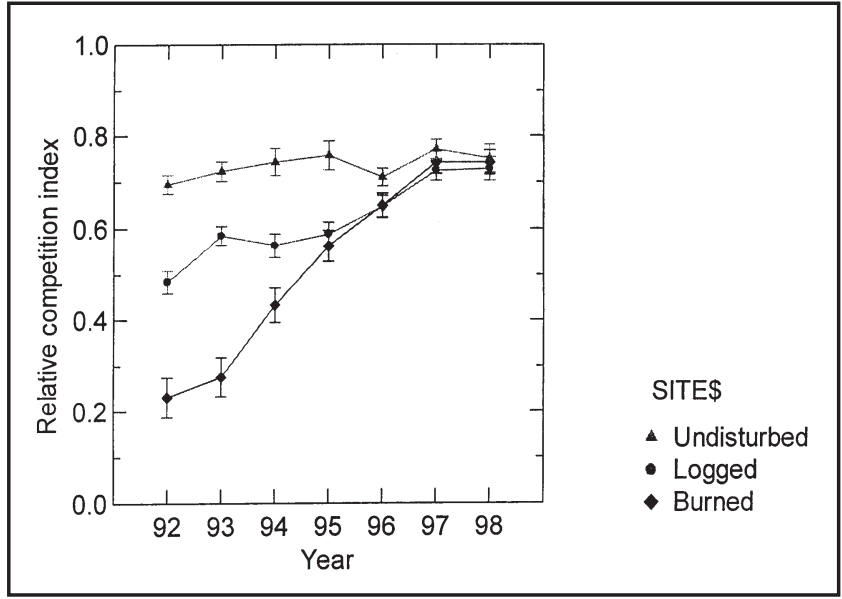

Fig. 2. Comparisons of relative competition intensity (RCI) calculated based on annual height growth, among the three types of plantation at different years. Error bars shown are standard errors.

petition dynamics (as measured by RCI) during the past seven years (Fig. 2). We believe that the difference in the initial disturbance type/intensity has created the different competition dynamics among the three sites. Different disturbance types/intensities likely produced different degrees of modification on physical site conditions, which directly affect early seedling growth as well as the composition and recovery rate of competing vegetation. With the highest intensity, fire promoted regeneration of aspen through suckering and created a more dynamic competition environment (RCI ranged 0.23 to 0.74 from 1992 to 1998). On the other extreme, seedlings planted under-canopy were only subjected to the minimum disturbance of initial trenching and planting activities and have been exposed to a stable but intense competition environment (RCI ranged 0.70 to 0.76 from 1992 to 1998). Logging and trenching created intermediate disturbance intensity and promoted recovery of existing shrub species as well as regeneration of aspen (RCI ranged 0.48 to 0.73 from 1992 to 1998 ). Although RCI could not be assessed for early planting years prior to 1992, height growth on the disturbed (burned or logged) sites was significantly better than that on the undisturbed site. These results indicated that competition intensity, especially during early plantation establishment, was quite different among the three sites. Stem analysis on five individuals of each major competing species suggested different growth dynamics among competing species. On the burned site, the major competitor (aspen) grew more 
than $1 \mathrm{~m}$ in the first year, more than $3 \mathrm{~m}$ in the first five years, and reached about $10 \mathrm{~m}$ in 1998 . Shrubs have not yet developed into major competitors on the burned site. On the logged site, aspen also grew immediately after disturbance but at significantly less abundance. The major competitors were shrubs (mainly beaked hazel and mountain maple), which developed immediately after logging and took about 5-6 years to grow to $1.5 \mathrm{~m}$, and ranged between 1.5 to $3 \mathrm{~m}$ tall in 1998. On the undisturbed site, the major competitor (beaked hazel) had already reached mature canopy height (about $3 \mathrm{~m}$ ) at the time of planting. In the future, it is likely that the shrub canopy will remain relatively stable due to its slow growth, while trembling aspen will soon enter the self-thinning stage due to its continuously fast growth. Therefore, competition dynamics will continue to differ among the three sites.

When making silvicultural decisions on vegetation management, it is critical to understand competition dynamics associated with each major competing species during the entire phase of seedling establishment. Static assessment of competition, although effective in describing the current competition environment, may not reflect the competition environment in the past or the future. Results from this case study suggested that, by affecting the development of competing vegetation, the type/intensity of past disturbances created different competition dynamics for black spruce seedlings planted on the burned, logged and undisturbed sites. The less intensive competition and fast height growth observed on the burned sites suggest that black spruce plantations established after fire require less effort in vegetation management; thus, planting after fire appears to be a cost-effective way to facilitate conifer regeneration.

As a retrospective case study, several limitations must be noted. Firstly, the study did not have replication for each treatment. Consequently, its result may be only applicable to the same forest type under the same environmental conditions in the region. Secondly, the three plantations were established at different years (1988 on the logging site, 1985 on the undisturbed site, 1984 on the burned site). This difference in plantation age, although small, may complicate growth comparisons based on calendar year, as both growth rate and competition (shade) tolerance may change with seedling age or size (Givinsh 1988). Thirdly, year-to-year climatic fluctuation and differences in initial planting stock may complicate comparison based on plantation age. Finally, RCI values based on height increment could not be extended prior to 1992 due to lack of competitionfree seedlings. To overcome these limitations, a replicated experimental study was started in 1999 to compare growth performance and competition dynamics between fire and logging plantations in the study area. This long-term study is designed to test the hypothesis that the differential growth between plantations established after fire and logging is caused by differences in competition dynamics (i.e., the change of relative competition intensity with disturbance age) due to the type/intensity of the disturbance.

\section{Acknowledgements}

The research was supported by the Natural Sciences and Engineering Council of Canada and Manitoba Hydro. We thank Kevin Kemball, Yuebing Hu and Aurea Simmens for their field and laboratory assistance, and Daniel Philippot for providing information on plantation establishment. Kevin Kemball was partially supported by the Science and Technology Youth Internship program of Natural Resource Canada while Aurea Simmens was supported by NSERC summer undergraduate student award.

\section{References}

Bergeron, Y. and M. Dubuc. 1989. Succession in the southern part of the Canadian boreal forest. Vegetatio 79: 51-63.

Brand, D.G. 1986. A competition index for predicting the vigour of planted Douglas-fir in southwestern British Columbia. Can. J. For. Res. 16: 23-29.

Burton, P.J. 1993. Some limitations inherent to static indices of plant competition. Can. J. For. Res. 23: 2142-2145.

Campbell, R.A. 1990. Herbicide use for forest management in Canada: Where we are and where we are going. For. Chron. 66: 91-96. Comeau, P.G., T.F. Braumandl and C.-Y. Xie. 1993. Effects of overtopping vegetation on light availability and growth of Engelmann spruce (Picea engelmannii) seedlings. Can. J. For. Res. 23: 2044-2048. Davis, M.A., K.J. Wrage and P.B. Reich. 1998. Competition between tree seedlings and herbaceous vegetation: support for a theory of resource supply and demand. J. Ecol. 86: 652-661.

Decagon Devices Inc. 1996. Sunfleck ceptometer reference guide. Decagon Devices, Inc. Pullman, Wash.

De Grandpre, L. and Y. Bergeron. 1997. Diversity and stability of understorey communities following disturbance in the southern boreal forest. J. Ecol. 85: 777-784.

De Grandpre, L., D. Gagnon and Y. Bergeron. 1993. Changes in the understorey of Canadian southern boreal forest after fire. J. Veg. Sci. 4: 803-810.

DeLong, S.C. 1991. The light interception index: a potential tool for assisting in vegetation management decisions. Can. J. For. Res. 21: $1037-1042$.

Givinsh, T.J. 1988. Adaptation to sun and shade: a whole -plant perspective. J. Plant. Physiol. 15: 63-92.

Jobidon, R. 1994. Light threshold for optimal black spruce (Picea mariana) seedling growth and development under brush competition. Can. J. For. Res. 24: 1629-1635.

Kneeshaw D.D., C. Messier, Y. Bergeron and D. Greene. 1999. Tree seedling and shrub interaction in closed forest vs. budworm gap understories: implications for forest management. In T.S. Veeman, D.W. Smith, B.G. Purdy, F.J. Salkie and G.A. Larkin (eds.). Proceedings of the 1999 SFMN conference, Science and Practice: Sustaining the Boreal Forest. pp. 494-499. Edmonton, AB.

LI-COR Inc. 1988. LI-1000 datalogger instruction manual. LICOR Inc., Lincon, Neb.

Lieffers, V.J., D. Macpherson and E.H. Hogg. 1993. Ecology and control strategies for Calamagrostis canadensis in boreal forest sites. Can. J. For. Res. 23: 2070-2077.

MacIsaac, D.A., S. Navratil. 1996. Competition dynamics in juvenile boreal hardwood-conifer mixture. In Comeau, P.G. and K. Thomas (eds.). Silviculture of Temperate and Boreal Broadleaf-conifer Mixture. pp. 23-34. Land Management Handbook 36. B.C. Ministry of Forests.

Malik, V. and V.R. Timmer. 1998. Biomass partitioning and nitrogen retranslocation in black spruce seedlings on competitive mixedwood sites: a bioassay study. Can. J. For. Res. 28: 206-215.

Markham, J.H. and C.P. Chanway. 1996. Measuring plant neighbor effects. Functional Ecol.. 10: 548-549.

Puettmann, K.J. and P.B. Reich. 1995. The differential sensitivity of red pine and quaking aspen to competition. Can. J. For. Res. 25: 1731-1737.

Reed, K.C., J.S. Shumay, R.B. Walker and C.S. Bledsoe, C.S. 1983. Evaluation of the interaction of two environmental factors affecting Douglas-fir seedling growth: Light and nitrogen. For. Sci. 29: 193-203. Wagner, R.G. and R. Radosevich. 1991. Neighbourhood predictors of interspecific competition in young Douglas-fir plantation. Can. J. For. Res. 21: 821-828. 
Wagner, R.G. 1994. Towards integrated forest vegetation management. J. For. 92: 26-30.

Walstad, J.D. and P.J. Kuch (eds.). 1987. Forest vegetation management for conifer production. John Wiley and Sons Inc., New York. Wang, G.G., K. Klinka and I. Moss. 1994. Guide to estimating interior spruce site index from edaphic factors in the Sub-boreal Spruce zone. Contract Report, Northwood Pulp and Timber Ltd., Prince George, B.C. 23 p.

Wang, G.G., J. Su and J.R. Wang. 2000. Height growth of planted black spruce seedlings in response to interspecific vegetation competition: a comparison on four competition measures at two measuring positions. Can. J. For. Res. 30: 573-579.
Wilson, S.D. and P.A. Keddy. 1986. Measuring diffuse competition along an environmental gradient, results from a shoreline plant community. American Naturalist 127: 862-869.

Wilkinson, L. 1990. SYSTAT: The system for statistics. SYSTAT Inc., Evanston, IL. 677 p. 